\title{
Pengaruh Kekayaan Daerah, Jenis Pemerintahan, Dan Kualitas Audit Terhadap Pengungkapan Internet-Based Financial Reporting
}

\author{
Sari Kurniati ${ }^{1)}$ Purnama Siddi ${ }^{2}$ \\ ${ }^{1)}$ Fakultas Ekonomi, Universitas Islam Batik Surakarta \\ arikade2003@gmail.com \\ ${ }^{2)}$ Fakultas Ekonomi, Universitas Islam Batik Surakarta \\ purnamasiddi.1104@gmail.com
}

\begin{abstract}
This study aims to get empirical evidence related to the effect of wealth, complexity, local government type, and audit quality on the disclosure of internet-based financial reporting (IBFR) local governments in Java. The population is all local government districts/cities in Java in 2018. The sample was selected using purposive sampling method and obtained 102 local governments consisting of 26 local governments that publish their financial reports through its website and 76 local governments do not publish reports finance through the website. The method of analysis used in the study is the logistic regression. The results of this study indicate that the wealth of local government, the complexity of local government, local government types, and quality audits increase the likelihood of disclosure IBFR.

Keyword: local government, wealth of local government, the complexity of local government, local government types, quality audits, and internet-based financial reporting.
\end{abstract}

\begin{abstract}
Abstrak
Penelitian ini bertujuan untuk memperoleh bukti empiris terkait dengan pengaruh kekayaan pemerintah daerah, kompleksitas pemerintah daerah, tipe pemerintah daerah, dan kualitas audit terhadap pengungkapan internet-based financial reporting (IBFR) pemerintah daerah di Jawa. Populasi yang digunakan adalah seluruh pemerintah daerah kabupaten/kota di Jawa tahun 2018. Sampel dipilih menggunakan purposive sampling method dan diperoleh 102 pemerintah daerah yang terdiri dari 26 pemerintah daerah yang mempublikasikan laporan keuangannya melalui website dan 76 pemerintah daerah yang tidak mempublikasikan laporan keuangan melalui website. Metode analisis yang digunakan dalam penelitian adalah logistic regression. Hasil dari penelitian ini menunjukkan bahwa kekayaan pemerintah daerah, kompleksitas pemerintah daerah, tipe pemerintah daerah, dan kualitas audit meningkatkan kemungkinan pengungkapan IBFR.

Kata kunci : pemerintah daerah, kekayaan daerah, kompleksitas, jenis pemerintah daerah, kualitas audit, internetbased financial reporting
\end{abstract}

\section{PENDAHULUAN}

Tingkat penggunaan teknologi internet oleh organisasi di Indonesia masih bervariasi, baik organisasi publik maupun non publik. Teknologi internet ini merupakan salah satu bentuk dari perkembangan teknologi informasi dan komunikasi yang telah berkembang dengan pesat dan telah mempengaruhi perekonomian yang ditandai dengan proses digitalisasi pertukaran informasi. Termasuk informasi mengenai penyampaian laporan keuangan suatu organisasi agar lebih mudah dan cepat untuk diakses. Selain internet, perkembangan teknologi informasi dan komunikasi dapat berupa intranet, ekstranet, e-government dan bentuk teknologi lainnya. Penelitian yang dilakukan oleh West (2005), menunjukkan lebih dari 19\% dari seluruh organisasi pemerintah daerah di seluruh dunia mengadopsi e-government dengan tingkatan yang berbeda.

Menurut Bonson dan Escobar (2005), proses digitalisasi terjadi di semua organisasi dikarenakan biaya relatif lebih murah dalam penyampaian informasi yang dapat meningkatkan dan memudahkan tingkat entitas ekonomi yang sebelumnya dilakukan secara manual dan konvensional. Media penyampaian laporan keuangan ini dapat melalui website yang dimiliki 
oleh organisasi public maupun non public. Pada organisasi sektor public dapat kita jumpai penggunaan website dalam pemerintah daerah sebagai salah satu sarana untuk menyampaikan akuntabilitas pelaksanaan anggaran pemerintah daerah kepada masyarakat. Salah satu bentuk transparansi dan akuntabilitas pemerintah daerah dalam riset yang dilakukan di beberapa negara adalah dengan mempublikasikan laporan keuangan di internet (Laswad et al., 2005).

Pelaporan keuangan oleh organisasi non public melalui website merupakan wahana bagi perusahaan untuk mengkomunikasikan berbagai informasi dan pengukuran secara ekonomi mengenai sumber daya yang dimiliki serta kinerja kepada berbagai pihak yang mempunyai kepentingan atas informasi tersebut. Hal tersebut tidak jauh berbeda pada sektor public, website pada pemerintah daerah merupakan salah satu sarana untuk mengkomunikasikan informasi atas akuntabilitas pelaksanaan anggaran pemerintah daerah kepada publik. Tujuan lain dari adanya website adalah sebagai media penyampaian laporan keuangan agar lebih mudah dan cepat untuk diakses (Kusumawati, 2003). Sedangkan Sandoval-Almazan (2011) berpendapat bahwa portal website tidak hanya sebagai saluran untuk memberikan informasi dan layanan pemerintah, tetapi juga sebagai alat yang ampuh untuk bertukar informasi dan pengetahuan antar aktor sosial yang berbeda serta entitas pemerintah untuk memungkinkan berpartisipasi dalam upaya pengambilan keputusan kolektif tentang urusan publik yang penting. Terkait dengan kemudahan dan cepatnya mengakses informasi dalam suatu website, maka hampir seluruh pemerintah daerah di Indonesia menggunakannya. Website pemerintah daerah memuat berbagai macam informasi tentang daerah tersebut dan ada pula yang telah memanfaatkan untuk kegiatan public service, sosialisasi pengumuman dan peraturan daerah serta sebagai sarana komunikasi secara interaktif terhadap warga masyarakatnya.

Pemanfaatan media elektronik website sebagai media penyampaian laporan keuangan dan berbagai macam informasi pemerintah daerah bukanlah tidak berdasar, namun merujuk pada beberapa Negeri Nomor peraturan pemerintah. Sebagaimana Peraturan Menteri Dalam Negeri 7A Tahun 2007 (Permendagri No. 7A Tahun 2007) Tentang Tatacara Penyampaian Informasi dan Tanggapan atau Saran dari Masyarakat atas Laporan Penyelenggaraan Pemerintahan Daerah Bab I perihal Ketentuan Umum Pasal 1 poin (7), menyebutkan bahwa "Informasi Laporan Penyelenggaraan Pemerintahan Daerah adalah informasi penyelenggaraan pemerintahan daerah kepada masyarakat melalui media yang tersedia di daerah". Begitu juga halnya dengan dua peraturan pendukung lainnya yaitu Peraturan Pemerintah Republik Indonesia Nomor 3 Tahun 2007 (PP No. 3 Tahun 2007) tentang Laporan Penyelenggaraan Pemerintah Daerah Kepada Pemerintah, Laporan Keterangan Pertanggungjawaban Kepala Daerah Kepada DPRD, dan Informasi Laporan Penyelenggaraan Pemerintah Daerah Kepada Masyarakat dan peraturan lainnya adalah Peraturan Pemerintah Republik Indonesia Nomor 6 Tahun 2008 (PP No. 6 Tahun 2008) tentang Pedoman Evaluasi Penyelenggaraan Pemerintahan Daerah.

Beberapa penelitian terdahulu telah dilakukan berkaitan dengan pelaporan keuangan di internet oleh pemerintah daerah. Laswad (2005) melakukan penelitian terkait dengan kompetisi politik, size, leverage, kekayaan kota, visibilitas pers, dan jenis otoritas lokal sebagai penentu pelaporan keuangan sukarela di internet pada pemerintah daerah di Selandia Baru. Hasil penelitian yang diperoleh menunjukkan bahwa leverage, kekayaan kota, visibilitas pers, dan jenis otoritas lokal berhubungan dengan praktek pelaporan keuangan di internet pada pemerintah daerah di Selandia Baru. Sementara itu, Puspita dan Dwi (2011) meneliti pengaruh ketergantungan kota, ukuran, kompleksitas kota, dan belanja kota terhadap pengungkapan sukarela berbasis internet. Hasil penelitian yang didapat adalah ketergantungan kota dan ukuran berpengaruh terhadap jumlah pengungkapan sukarela berbasis internet, sementara itu, 
kompleksitas kota, dan belanja kota tidak berpengaruh terhadap pengungkapan sukarela berbasis internet. Hilmi dan Dwi (2012), melakukan penelitian terkait dengan pengaruh karakteristik, kompleksitas dan hasil audit pemerintah provinsi terhadap tingkat pengungkapan. Hasil penelitian yang diperoleh menunjukkan bahwa tingkat pengungkapan yang dilakukan oleh pemerintah provinsi masih rendah. Martani dan Annisa (2012) mengungkapkan perihal kasus pengungkapan laporan keuangan di pemerintah dengan cara menguji pengaruh kualitas audit, insentif manajemen dan karakteristik pemerintah daerah terhadap pengungkapan laporan keuangan pemerintah daerah. Hasilnya menunjukkan bahwa ketiga hal tersebut dapat menjelaskan tingkat pengungkapan.

\section{TINJAUAN PUSTAKA DAN PENGEMBANGAN HIPOTESIS \\ Grand Theory \\ Teori Legitimasi}

Gray et al (2001) berpendapat mengenai legitimacy theory, yang mana teori legitimasi adalah: “... a systems oriented view of organization and society...permits us to focus on the role of information and disclosure in the relationship between organizations, the state, individuals an group". Definisi ini mengisyaratkan bahwa legitimasi merupakan sistem pengelolaan suatu organisasi yang berorientasi pada keberpihakan terhadap masyarakat (society), pemerintah, individu dan kelompok masyarakat. Untuk itu, sebagai suatu sistem yang mengedepankan keberpihakan kepada society, kegiatan operasi organisasi harus sesuai dengan harapan masyarakat.annual report.

\section{Teori Signaling}

Teori signal ini menjelaskan bahwa organisasi pemerintah berusaha untuk memberikan signal kepada masyarakat, yaitu salah satunya dengan cara menyajikan laporan keuangan yang berkualitas dan terperinci. Puspita dan Martani (2012), Trisnawati dan Achmad (2014), dan Martani et al (2014) megungkapkan bahwa signalling theory menjelaskan mengenai pemerintah sebagai pemegang amanah rakyat berusaha untuk dapat menunjukkan sinyal yang positif kepada masyarakat. Evans dan Patton (1987) dalam Hilmi (2011) menyatakan bahwa dalam konteks signalling theory pemerintah berusaha untuk memberikan sinyal yang baik kepada rakyat agar rakyat dapat terus mendukung kegiatan pemerintah yang berjalan saat ini. Salah satu sinyal baik yang diberikan oleh pemerintah kepada rakyat adalah dengan menerbitkan laporan keuangan sebagai bentuk pertanggungjawaban ataupun sebagai bentuk promosi politik bahwa pemerintah telah menjalankan tugasnya dengan baik sehingga dapat meningkatkan reputasi pemerintah di mata rakyat (Hilmi dan Martani, 2012). Penerbilan laporan keuangan tersebut dapat melalui website pemerintah daerah sebagai wujud pemaparan transparansi informasi ke publik.

\section{Teori Stewardship}

Teori stewardship dapat diterapkan pada penelitian akuntansi sektor publik seperti organisasi pemerintahan (Thornton, 2009) yang sejak awal perkembangannya, akuntansi organisasi sektor publik telah dipersiapkan untuk memenuhi kebutuhan informasi bagi hubungan antara stewards dengan principals. Teori stewardship ini menggambarkan situasi dimana para manajer tidaklah termotivasi oleh tujuan-tujuan individu seperti materi dan uang tetapi lebih ditujukan pada sasaran hasil utama mereka untuk kepentingan organisasi (Raharjo, 2007). Khasanah dan Rahardjo (2014) mengungkapkan bahwa pemerintah sebagai pihak yang memiliki banyak informasi dan bertanggungjawab atas kepercayaan yang telah diberikan rakyat (dalam masa pemilu) memiliki kesadaran untuk terus mewujudkan transaparansi dan akuntabilitas melalui pengungkapan Laporan Keuangan Pemerintah Daerah (LKPD) yang baik. Hal ini 
dilakukan sebagai upaya aktualisasi diri sebagai pegawai pemerintah yang patuh maupun untuk tujuan politik seperti mencari simpati agar dapat terpilih kembali pada pemilu berikutnya, dan sebagai upaya dalam mendapatkan kepercayaan publik.

\section{Laporan Keuangan Sektor Publik}

Menurut Bastian (2006), laporan keuangan sektor publik adalah representasi dari posisi keuangan dari sejumlah transaksi sektor yang dilakukan oleh suatu entitas sektor publik. Adapun bentuk dan penyusunan laporan keuangannya dapat dipengaruhi oleh berbagai faktor, seperti sifat lembaga sektor publik, sistem pemerintahan suatu negara, mekanisme pengelolaan keuangan, dan sistem anggaran negara. Empat faktor tersebut mempengaruhi karakteristik akuntansi sektor publik, dan dapat sebagai pembeda antara laporan keuangan sektor publik dengan sektor swasta. Laporan keuangan sektor publik yang dilaporkan oleh pemerintah daerah disebut sebagai Laporan Keuangan Pemerintah Daerah (LKPD). Standar Akuntansi Pemerintahan (SPAP) Nomor 1 tentang penyajian laporan keuangan, menyatakan bahwa laporan keuangan merupakan laporan yang terstruktur mengenai posisi keuangan dan transaksi-transaksi yang dilakukan oleh suatu entitas pelaporan. Tujuan umum laporan keuangan ini adalah untuk menyajikan informasi mengenai posisi keuangan, realisasi anggaran, arus kas, dan kinerja keuangan suatu entitas pelaporan yang bermanfaat bagi para pengguna untuk membuat dan mengevaluasi keputusan mengenai alokasi sumber daya. Oleh karena itu, dalam rangka memenuhi tujuan umum atas laporan keuangan daerah tersebut, maka dalam penyajian laporan keuangan harus menyediakan informasi mengenai Laporan Realisasi Anggaran (LRA), Neraca, Laporan Arus Kas, dan Catatan atas Laporan Keuangan (CaLK).

\section{Pengungkapan Informasi Laporan Keuangan}

Suhardjanto (2010) menyatakan bahwa laporan keuangan sebagai bentuk akuntabilitas public menggambarkan kondisi yang komprehensif tentang kegiatan operasional, posisi keuangan, arus kas, dan penjelasan atas pos-pos yang ada di dalam laporan keuangan tersebut. Peraturan Pemerintah Nomor 24 Tahun 2005 tentang Standar Akuntansi Pemerintahan menyebutkan bahwa laporan keuangan disusun untuk menyediakan informasi yang relevan mengenai posisi keuangan dan seluruh transaksi yang dilakukan oleh suatu entitas pelaporan selama satu periode pelaporan.

Menurut Suwardjono (2005), secara umum, tujuan dari pengungkapan (disclosure) pada laporan keuangan adalah menyajikan informasi yang dipandang perlu untuk mencapai tujuan pelaporan keuangan dan untuk melayani berbagai pihak yang memiliki kepentingan yang berbeda-beda. Rahman et al. (2013) menjelaskan bahwa pengungkapan dimaksudkan untuk menyediakan informasi yang dapat membantu keefektifan pengambilan keputusan bagi pengguna dan apa yang harus diungkapkan kepada publik dibatasi dengan apa yang dipandang bermanfaat bagi pemakai yang dituju. Sementara itu untuk tujuan pengawasan, informasi tertentu harus disampaikan kepada badan pengawasan berdasarkan peraturan melalui formulir-formulir yang menuntut pengungkapan secara rinci. Pengungkapan (disclosure), menurut Chariri (2003), dikelompokkan menjadi dua, yaitu pengungkapan yang bersifat wajib (mandatory disclosure) serta pengungkapan yang bersifat sukarela (voluntary disclosure). Evans (2003) dalam Suwardjono (2005) mengklasifikasikan tiga tingkat dari pengungkapan yaitu, pengungkapan memadai (adequate disclosure), pengungkapan wajar (fair or ethical disclosure), dan tingkat penuh (full disclosure).

\section{Pelaporan Keuangan di Internet}

Pelaporan keuangan daerah merupakan wahana bagi pemerintah daerah untuk mengkomunikasikan berbagai informasi dan pengukuran secara ekonomi mengenai sumber daya 
yang dimiliki serta kinerja kepada berbagai pihak yang mempunyai kepentingan atas informasi tersebut. Informasi akan mempunyai manfaat jika disampaikan tepat waktu kepada para pemakainya guna pengambilan keputusan. Semakin cepat waktu peyajian laporan keuangan, maka akan semakin baik untuk pengambilan keputusan (Mardiasmo, 2009). Berdasarkan penelitan Rahman (2013), pemerintah daerah telah menggunakan media internet untuk menyampaikan informasi kepada pengguna dan melalui website pemerintah daerah tersebut informasi akan tersampaikan dengan tepat waktu. Proses digitalisasi terjadi di semua organisasi disebabkan oleh biaya yang relatif lebih murah ketika menggunakan teknologi dalam menyampaikan suatu informasi serta kekuatan dari teknologi informasi dan komunikasi yang dapat meningkatkan dan memudahkan tingkat aktivitas entitas ekonomi yang sebelumnya dilakukan dengan manual dan konvensional (Bonson dan Escobar, 2005). Riset di beberapa negara menunjukkan bahwa salah satu bentuk transparansi dan akuntabilitas pemerintah daerah dilakukan dengan mempublikasikan laporan keuangan di internet (Laswad et al, 2005). Berdasarkan temuan penelitian sebelumnya, untuk menguji konsistensinya maka hipotesis penelitian pertama adalah sebagai berikut: $\mathbf{H}_{1}$ : Pemerintah daerah dengan kekayaan yang besar akan cenderung melakukan pengungkapan IBFR.

\section{Kompleksitas Pemerintah Daerah dan Pengungkapan IBFR}

Hilmi dan Martani (2012) menyatakan bahwa jumlah penduduk merupakan proksi dari kompleksitas pemerintah. Pasal 28 ayat 2 Undang-Undang No. 33 Tahun 2004 menyebutkan bahwa jumlah penduduk merupakan salah satu hal yang mencerminkan besarnya kebutuhan pendanaan akan penyediaan layanan publik di setiap daerah. Menurut Ingram (1984), kompleksitas pemerintahan yang diukur melalui jumlah orang akan mendorong pemerintah negara bagian untuk meningkatkan pengungkapan dalam laporan keuangannya. Sejalan dengan konsep teori signaling, Martani dan Liestiani (2012) menambahkan bahwa populasi penduduk yang lebih besar berarti pemerintah harus memberikan pelayanan publik yang jauh lebih juga kepada masyarakatnya. Dengan demikian, penduduk yang besar akan meningkatkan kompleksitas pemerintah dalam menjalankan fungsinya sebagai pelayan masyarakat. Semakin besar populasi penduduk maka semakin besar pula tuntutan akan pengungkapan yang dilakukan oleh pemerintahnya dikarenakan fungsi pemerintah pada dasarnya adalah sebagai abdi masyarakat. Liestiani (2008) menemukan bahwa jumlah penduduk berkorelasi positif dan signifikan terhadap tingkat pengungkapan. Ingram (1984) dan Robbins dan Austin (1986) juga menemukan hubungan yang positif meski tidak signifikan terhadap tingkat pengungkapan. Berdasarkan temuan penelitian sebelumnya, untuk menguji konsistensinya maka hipotesis penelitian ini adalah $\mathbf{H}_{2}$ :Pemerintah daerah dengan tingkat kompleksitas yang tinggi akan cenderung melakukan pengungkapan IBFR.

\section{Tipe Pemerintah Daerah dan Pengungkapan IBFR}

Tipe pemerintah daerah adalah jenis pemerintah daerah tingkat dua apakah berbentuk kota atau kabupaten (Rahman et al, 2013). Penelitian Serrano, et al (2008) menyatakan bahwa pada otoritas lokal (pemerintah daerah) yang menggunakan teknologi informasi yang jauh lebih tinggi akan merangsang pemerintahannya untuk memberikan layanan informasi berupa pengungkapan transparansi keuangan pemerintah melalui internet. Sejalan dengan konsep teori stewardship yang menggambarkan situasi dimana para manajer tidaklah termotivasi oleh tujuan-tujuan individu seperti materi dan uang tetapi lebih ditujukan pada sasaran hasil utama mereka untuk kepentingan organisasi. Hal ini berarti pihak pemerintah daerah tingkat dua (yang berbentuk kota/kabupaten) merupakan bagian dari pemerintahan diatasnya, yaitu pemerintah provinsi ataupun pusat. Selayaknya hubungan antara steward dan principal maka pemerintah daerah 
kabupaten/kota secara langsung ataupun tidak akan berkewajiban untuk menyampaikan penggunaan dananya baik yang berasal dari bantuan pemerintah atasnya atau dari dananya sendiri untuk dilaporkan dengan salah satu caranya adalah melalui publikasi di masing-masing website pemerintah daerah.

Penelitian Laswad et al, (2005) menerangkan bahwa pada tipe wilayah regional (kabupaten) masih kurang dalam hal tingkat pengungkapan secara sukarela di internet, sedangkan pada tipe wilayah city (kota) dan district (provinsi) tingkat pengungkapannya lebih tinggi. Hal ini dimungkinkan karena tingkat masyarakat dalam mengakses internet masih kurang pada tipe wilayah regional. Sejalan dengan teori signaling, pemerintah daerah sebagai pemegang amanah rakyat serta pemegah amanah dari pemerintah pusat, akan menunjukkan sinyal yang positif dengan mempublikasikan laporan keuangannya sebagai bagian dari kewajibannya.

Penelitian di Indonesia yang dilakukan oleh Rahman et al (2013) menyebutkan bahwa daerah perkotaan adalah tujuan urbanisasi dengan karakteristik masyarakatnya heterogen, berbagai macam kebudayaan, pekerjaan, tingkat pendidikan, serta tingkat kekayaan yang berimplikasi terhadap kecenderungan masyarakat perkotaan dalam mengakses internet cenderung lebih tinggi. Kecenderungan ini membuat pengawasan di daerah kota akan lebih tinggi, sehingga kecenderungan pemerintahan untuk secara sukarela melaporkan keuangan mereka juga lebih tinggi karena adanya tuntutan transparansi keuangan. Berdasarkan temuan penelitian sebelumnya, untuk menguji konsistensinya maka hipotesis penelitian ini adalah H3:Pemerintah daerah dengan jenis tipe pemerintah kota akan cenderung melakukan pengungkapan IBFR.

\section{Kualitas Audit Pemerintah Daerah dan Pengungkapan IBFR}

Kualitas audit dicerminkan dari opini penilaian masing-masing daerah yang diberikan oleh BPK. Opini disini adalah pernyataan profesional atas kesimpulan pemeriksa mengenai tingkat kewajaran informasi yang tersaji dalam laporan keuangan (Undang-Undang Nomer 15 tahun 2004). Pemeriksaan laporan keuangan pemerintah daerah akan menghasilkan opini audit, yaitu terdiri atas opini Tidak Memberikan Pendapat (disclaimer of opinion), Tidak Wajar (Adverse Opinion), Wajar Dengan Pengecualian (Qualified Opinion), dan Wajar Tanpa Pengecualian (Unqualified Opinion). Opini Wajar Tanpa Pengecualian/WTP dianggap pemerintah daerah sebagai opini yang paling baik sebagai wujud penghargaan atas pengelolaan keuangan daerah yang dikelola dengan handal dan dapat dipertanggungjawabkan. Oleh karena itu, sesuai dengan teori signalling, pemerintah daerah cenderung akan mengungkapkan informasi keuangan melalui website-nya apabila mendapatkan opini ini. Hal ini dianggap sebagai berita baik sebagai sinyal atas pengelolaan keuangan yang berhasil. Namun, jika sebaliknya, opini audit buruk dapat menimbulkan persepsi masyarakat bahwa pengelolaan keuangan tidak berhasil sehingga pemerintah daerah cenderung menutupi informasi keuangan daerah dengan tidak menyajikannya pada website-nya.

Penelitian Copley (1991) menunjukkan bahwa kualitas audit mempengaruhi tingkat pengungkapan. Pada penelitian tersebut, perusahaan audit terkemuka akan mendorong pemerintah kota (municipals) untuk membuat lebih banyak keterbukaan dan memenuhi pengungkapan yang diperlukan oleh standar akuntansi. Hal ini dikarenakan kualitas auditor yang baik akan mendeteksi banyak kelemahan dan temuan dan setelah itu memberikan beberapa rekomendasi untuk meningkatkan keterbukaan. Begitu pula penelitian yang dilakukan oleh Martani dan Liestiani (2012) juga menunjukkan bahwa kualitas audit akan meningkatkan tingkat pengungkapan.Berdasarkan temuan penelitian sebelumnya, untuk menguji konsistensinya, maka 
hipotesis penelitian ini adalah sebagai berikut. H4: Pemerintah daerah dengan kualitas audit paling baik akan cenderung melakuan pengungkapan IBFR.

\section{METODE PENELITIAN}

Data yang digunakan dalam penelitian ini menggunakan data sekunder yang telah dipublikasikan oleh masing - masing pemerintah daerah melalui websitenya ditambah dengan data dari pusat informasi dan komunikasi BPK berupa data dari laporan keuangan pemerintah daerah (LKPD) kota/kabupaten di Jawa pada tahun 2018. Pengambilan sampel dalam penelitian ini menggunakan teknik purposive sampling, yaitu dengan menggunakan kriteria sebagai berikut:

1. Pemerintah daerah kabupaten/kota di Indonesia yang menerbitkan laporan keuangan pemerintah daerah 2013 dan diaudit oleh BPK RI serta menyajikan data dan informasi guna pengukuran variabel penelitian.

2. Pemerintah daerah kabupaten/kota yang mempunyai website dan dapat diakses guna perolehan data penelitian.

3. Pemerintah daerah yang mempublikasikan informasi terkait laporan keuangan pada website mereka.

Metode analisis yang digunakan dalam penelitian ini adalah uji statistik deskriptif dan uji hipotesisnya menggunakan regresi logistik (logistic regression). Alasan penggunaan analisis regresi logistik adalah dikarenakan variabel dependen bersifat dikotomi (mengungkapkan dan tidak mengungkapkan). Teknik analisis dalam mengolah data ini tidak memerlukan lagi uji normalitas dan uji asumsi klasik pada variabel bebasnya (Ghozali, 2011: 225). Variabel dependen pada penelitian ini, yaitu Pengungkapan IBFR, diukur dengan skala nominal. Skala nominal yang dimaksud adalah variabel dummy dengan nominal 1 dan 0 . Nilai 1 untuk pemerintah daerah yang mengungkapkan Laporan Keuangan Pemerintah Daerah (LKPD) pada websitenya dan nilai 0 untuk yang tidak mengungkapkan LKPD.

Untuk melakukan analisis regresi logistik, dilakukan pengujian kelayakan model regresi, menilai keseluruhan model, koefisien determinasi, dan pengujian simultan. Model atau rumus regresi logistik digunakan untuk menguji hipotesis. Langkah-langkah yang harus dilakukan untuk menguji hipotesis dengan melakukan Uji Nilai Likelihood, Uji Nilai Hosmer and Lemeshow's Goodness of Fit Test, Uji Nilai Nagelkerke $\mathrm{R}^{2}$ dan Uji Estimasi Parameter dan Koefisien Regresi.

\section{Definisi Operasional Variabel dan Pengukuran Variabel Kekayaan Pemerintah Daerah}

Sebagaimana penelitian Ingram (1984) serta Martani dan Liestiani (2012) bahwa kekayaan pemerintah daerah atau wealth merupakan tingkat kekayaan daerah yang diukur dari PAD per kapita. Pada penelitian ini, pengukuran kekayaan pemerintah daerah diukur dengan proporsi total PAD dengan total jumlah penduduk yang dapat dirumuskan sebagai berikut.

\section{Kompleksitas Pemerintah Daerah}

$$
\text { Kekayaan Pemda }=\frac{\text { Total PAD }}{\text { Jumlah Penduduk }}
$$

Kompleksitas pemerintah daerah dicerminkan dari jumlah populasi penduduk dari suatu pemerintah daerah tingkat dua (kabupaten/kota). Mengutip Puspita dan Martani (2012) bahwa semakin banyak jumlah penduduk, maka semakin besar pula tuntutan akan pengungkapan yang harus dilakukan pemerintah daerah mengingat fungsi pemerintahan adalah sebagai abdi masyarakat. Ingram (1984) memaparkan bahwa variabel kompleksitas pemerintahan (yang diproksikan dengan jumlah penduduk) memberikan dorongan kepada pemerintah daerah untuk 
meningkatkan pengungkapan pada laporan keuangannya. Dalam penelitian ini, kompleksitas dirumuskan sebagai berikut.

\section{Tipe Pemerintah Daerah}

Kompleksitas Pemda $=\log ($ Populasi Jumlah Penduduk)

Tipe pemerintah daerah merupakan jenis pemerintah daerah yang ada di Indonesia, yaitu apakah tipe pemerintahan dalam bentuk kabupaten atau kota. Sebagaimana penelitian Laswad et al (2005) dan Rahman (2013), pengukuran variabel ini dinilai menggunakan variabel dummy. Angka 1 apabila pemerintah daerah berbentuk kota dan angka 0 untuk pemerintah daerah berbentuk kabupaten di Indonesia. Untuk menentukan tipe pemerintah daerah adalah sebagai berikut.

\section{Tipe Pemerintah Daerah $=$ Dummy variable, 1 jika kota dan 0 jika kabupaten.}

\section{Kualitas Audit Pemerintah Daerah}

Kualitas audit merupakan opini hasil pemeriksaan audit BPK atas laporan keuangan pemerintah daerahKualitas audit ini dapat dinilai dari jenis opini yang diberikan oleh BPK kepada pemerintah daerah. Opini audit salah satu indikator kualitas akuntabilitas keuangan dilihat atas penyajian LKPD, secara bertingkat opini audit ini terdiri dari: Tidak Wajar (TW), Tidak Memberikan Pendapat (TMP), Wajar Dengan Pengecualian (WDP), dan yang terbaik adalah Wajar Tanpa Pengecualian (WTP). Pengukuran kualitas audit yang tercermin dari opini audit ini merujuk pada pengukuran yang dilakukan oleh Masyitoh et al (2015), yaitu menggunakan skor $\mathrm{WTP}=4, \mathrm{WDP}=3, \mathrm{TW}=2, \mathrm{TMP}=1$. Untuk menentukan kualitas audit maka diukur sebagai berikut.

\begin{tabular}{|c|c|}
\hline Opini BPK & Skor \\
\hline WTP & 4 \\
\hline WDP & 3 \\
\hline TW & 2 \\
\hline TMP & 1 \\
\hline
\end{tabular}

\section{HASIL DAN PEMBAHASAN}

Untuk menguji hipotesis, maka digunakan metode logistic regression dikarenakan variabel dependen pada penelitian ini yaitu Pengungkapan Internet-Based Financial Reporting (IBFR), diukur dengan skala nominal. Skala nominal yang dimaksud adalah variabel dummy dengan nominal 1 dan 0. Nilai 1 untuk pemerintah daerah yang mengungkapkan Laporan Keuangan Pemerintah Daerah (LKPD) pada websitenya dan 0 untuk yang tidak menyampaian LKPD.

Logistic regression adalah model regresi yang telah mengalami modifikasi, sehingga karakteristiknya sudah tidak sama lagi dengan model regresi sederhana atau berganda. Uji normalitas tidak perlu dilakukan jika pengujian menggunakan logistic regression (Ghozali, 2011). Selain itu penelitian ini juga mengabaikan uji asumsi klasik yang terdiri dari uji multikolinearitas, autokorelasi dan heteroskedastisitas. Untuk melakukan analisis regresi logistik, dilakukan pengujian kelayakan model regresi, menilai keseluruhan model, koefisien determinasi, dan pengujian simultan. Model atau rumus regresi logistik yang digunakan untuk menguji hipotesis adalah sebagai berikut.

$$
\operatorname{Ln} \frac{p}{1-p}=\beta_{0}+\beta_{1} \mathrm{KPD}+\beta_{2} \mathrm{KOM}+\beta_{3} \mathrm{TPD}+\beta_{4} \mathrm{KA}+\mathrm{e}
$$


Keterangan:

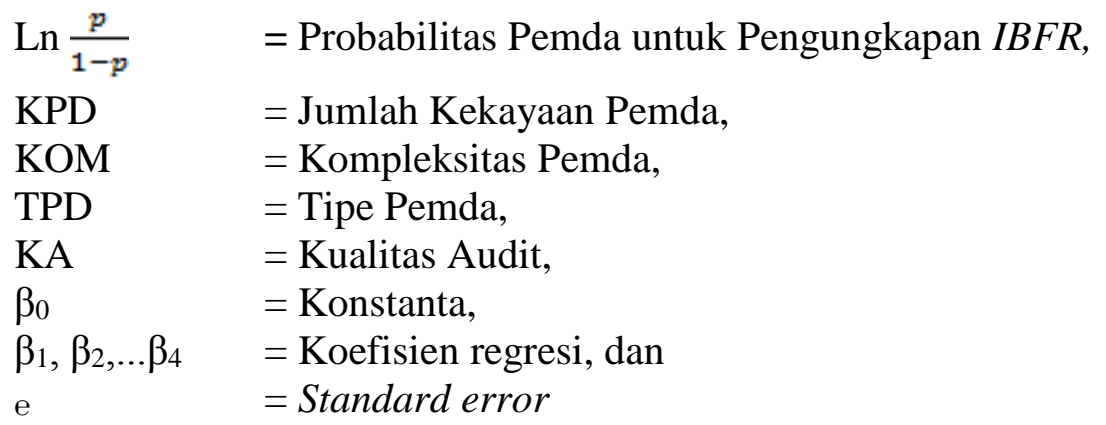

Berikut merupakan hasil pengujian koefisien regresi penelitian ini :

Table 2. Pengujian Koefisien Regresi

\begin{tabular}{lllll}
\hline Variabel & $\boldsymbol{B}$ & $\boldsymbol{S E}$ & Wald & Sign \\
\hline KPD & 0,000 & 0,000 & 5,661 & 0,017 \\
KOM & 0,975 & 0,293 & 11,048 & 0,001 \\
TPD & 0,637 & 0,301 & 4,483 & 0,034 \\
KA & 0,581 & 0,203 & 8,176 & 0,004 \\
Constanta & $-8,882$ & 1,827 & 23,634 & 0,000 \\
\hline \multicolumn{5}{c}{ Sumber: Olah data SPSS, 2019 } \\
& *Secara statistic signifikansi pada tingkat 5\% \\
\hline
\end{tabular}

Tabel di atas menunjukkan bahwa hasil pengujian koefisien regresi variabel kekayaan Pemda, kompleksitas, tipe pemda dan kualitas audit memiliki signifikansi lebih kecil dari 0,05 maka $\mathrm{H}_{\mathrm{a}}$ diterima. Hal ini berarti ada pengaruh yang signifikan antara kekayaan pemerintah daerah, kompleksitas, tipe pemerintah daerah dan kualitas audit terhadap Internet-Based Financial Reporting pemerintah daerah. Nilai estimasi yang benar (correct) dan salah (incorrect) dalam ketepatan prediksi ditunjukkan dalam tabel berikut ini

Tabel 3. Daya Klasifikasi Model

\begin{tabular}{lllll}
\hline Observed & & \multicolumn{2}{c}{ Predicted FD } & Percentage \\
& & Non IBFR & IBFR & Correct \\
\hline FD & Non IBFR & 59 & 3 & 96,8 \\
& IBFR & 36 & 5 & 13,0 \\
& & & & 76,1 \\
\multicolumn{2}{l}{ Overall Percentage } & & & \\
\hline
\end{tabular}

Berdasarkan tes keakuratan pengelompokan pemerintah daerah (Internet-Based Financial Reporting) dan pemerintah daerah (non Internet-Based Financial Reporting) pada tabel 5.2 yang ditunjukkan pada kolom merupakan dua nilai prediksi dari variabel yang tergantung pada kondisi pemerintah daerah, dalam hal ini pemerintah daerah yang menggunakan IBFR (1) dan pemerintah daerah yang tidak menggunakan IBFR/Non IBFR (0), sedangkan pada baris menunjukkan nilai observasi sesungguhnya dari variabel tergantung IBFR (1) dan non IBFR (0). Tabel di atas memberikan nilai overall percentage sebesar $76,1 \%$ yang berarti ketepatan model penelitian ini adalah sebesar 76,1\%.

Pengujian Hipotesis 1: Kekayaan pemda terhadap internet-based financial reporting

Hasil analisis terhadap pengaruh Internet-Based Financial Reporting menunjukkan bahwa untuk variabel kekayaan pemda (KPD) berpengaruh positif dan signifikan, hal ini ditunjukkan oleh nilai signifikansi sebesar 0,017. Pengaruh positif menunjukkan bahwa semakin tinggi tingkat kekayaan daerah akan semakin mendorong pemerintah daerah untuk mengungkapkan 
keuangannya melalui internet. Tingkat kekayaan daerah yang tinggi juga bisa dianggap sebagai wujud keberhasilan pemerintah daerah dalam meningkatkan kinerjanya, hal ini merupakan sinyal positif bagi daerah baik secara ekonomi maupun positif. Hasil penelitian ini konsisten dengan penelitian yang dilakukan oleh Ingram (1984), Christiaens (1999), Craven dan Marston (1999), Laswad et al (2005), Martani dan Liestiani (2012), Puspita dan Martani (2012), Rahman et al (2013), dan Trisnawati dan Achmad (2014) dimana dalam penelitiannya menunjukkan bahwa kekayaan pemda berpengaruh positif dan signifikan terhadap Internet-Based Financial Reporting.

Pengujian Hipotesis 2: Pengaruh kompleksitas pemda terhadap internet-based financial reporting.

Hasil analisis terhadap kompleksitas (KOM) menunjukkan bahwa ukuran kompleksitas pemda berpengaruh positif dan signifikan terhadap Internet-Based Financial Reporting, hal ini ditunjukkan oleh nilai signifikansi sebesar 0,001. Pengaruh positif menunjukkan semakin besar populasi penduduk akan semakin mendorong pemerintah daerah untuk mengungkapkan laporan keuangannya. Kota dengan populasi penduduk yang besar akan semakin kompleks sehingga tuntutan untuk mengungkapkan laporan keuangannya. Hasil penelitian ini konsisten dengan penelitian yang dilakukan oleh Hilmi dan Martani (2012), Martani dan Liestiani (2012), Hendriyani dan Tahar (2015) dimana dalam penelitiannya menunjukkan bahwa kompleksitas pemda berpengaruh positif dan signifikan terhadap Internet-Based Financial Reporting.

\section{Pengujian Hipotesis: Pengaruh tipe pemda terhadap internet-based financial reporting}

Hasil analisis terhadap tipe pemda (TPD) menunjukkan bahwa tipe pemda berpengaruh positif dan signifikan terhadap Internet-Based Financial Reporting, hal ini ditunjukkan oleh nilai signifikansi sebesar 0,034. Pengaruh positif menunjukkan tipe pemerintahan kota cenderung lebih siap dalam mengungkapkan laporan keuangannya di internet, tuntutan warga kota yang lebih modern dan tingkat pendidikan yang lebih tinggi akan mendorong pemerintahannya untuk memberikan pelayanan yang lebih baik dibandingkan dengan pemerintahan kabupaten. Hasil penelitian ini konsisten dengan penelitian yang dilakukan oleh Laswad et al, (2005), Serrano, et al (2008) dan Rahman, et al (2013) dimana dalam penelitiannya menunjukkan bahwa pada otoritas lokal (pemerintah daerah) yang menggunakan teknologi informasi yang jauh lebih tinggi akan merangsang pemerintahannya untuk memberikan layanan informasi berupa pengungkapan transparansi keuangan pemerintah melalui internet.

\section{Pengaruh kualitas audit terhadap internet-based financial reporting.}

Hasil analisis terhadap kualitas audit (KA) menunjukkan bahwa kualitas audit berpengaruh positif dan signifikan terhadap Internet-Based Financial Reporting, hal ini ditunjukkan oleh nilai signifikansi sebesar 0,004. Pengaruh positif menunjukkan bahwa semakin baik hasil audit dari BPK akan semakin mendorong pemerintah daerah dalam mengungkapkan keuangannya melalui internet. Hasil penelitian ini konsisten dengan penelitian yang dilakukan oleh Copley (1991) dan Martani dan Liestiani (2012) dimana dalam penelitiannya menunjukkan bahwa kualitas audit akan meningkatkan tingkat pengungkapan.

\section{KESIMPULAN DAN SARAN}

Berdasarkan Hasil analisis data yang diperoleh penulis dari penelitian menjadi dasar untuk menarik kesimpulan yang dapat dinyatakan sebagai berikut.

1. Kekayaan pemda (KPD) berpengaruh positif dan signifikan terhadap pengungkapan Internet-Based Financial Reporting pemerintah daerah. Hal ini menunjukkan semakin baik 
tingkat kekayaan daerah akan meningkatkan motivasi pemerintah daerah untuk mengungkapkan laporan keuangannya di internet.

2. Kompleksitas pemda (KOM) berpengaruh positif dan signifikan terhadap pengungkapan Internet-Based Financial Reporting pemerintah daerah. Hal ini menunjukkan semakin besar populasi penduduk di daerah akan mendorong pemerintah daerah untuk mempublikasikan laporan keuangannya di internet.

3. Tipe pemda (TPD) berpengaruh positif terhadap pengungkapan Internet-Based Financial Reporting pemerintah daerah. Hal ini menunjukkan bahwa tipe pemerintahan kota cenderung untuk mempublikasikan laporan keuangannya melalui internet dan tipe pemerintahan kabupaten adalah sebaliknya.

4. Kualitas audit (KA) berpengaruh positif terhadap pengungkapan Internet-Based Financial Reporting pemerintah daerah. Hal ini menunjukkan bahwa semakin baik hasil audit BPK mendorong pemerintah daerah untuk mempublikasikan laporan keuangannya melalui internet.

Penelitian ini memiliki sejumlah keterbatasan baik dalam jumlah sampel maupun metodologi penelitian yang digunakan. Keterbatasan tersebut adalah sebagai berikut:

1. Periode data yang digunakan dalam penelitian masih relatif terbatas yaitu hanya satu tahun sehingga daya komparabilitas dan generalisasinya relatif kecil.

2. Sumber data yang digunakan adalah website pemda yang sebagian besar non aktif dan atau tidak dapat diakses.

3. Pengukuran pelaporan keuangan di internet menggunakan dummy tanpa mengakomodir kualitas konten.

\section{DAFTAR PUSTAKA}

Andriani, Evanti. Pengaruh Opini Audit dan Temuan Audit Terhadap Tingkat Pengungkapan Laporan Keuangan Pemerintah Daerah. Skripsi Akuntansi FE UI Depok. 2011.

Arifin, Imam dan Debby Fitriasari. 2014. Pengungkapan Laporan Keuangan Kementerian/Lembaga, Karakteristik Organisasi dan Hasil Audit BPK. Simposium Nasional Akuntansi XVII Ikatan Akuntan Indonesia. Mataram.

Bonson, E dan Escobar, T. 2005. A survey on voluntary disclosure on the internet: Empirical evidence from European Union companies. The International Journal of Digital Accounting Research 2: 27-51.

Copley, Paul A. 1991. The Association Between Municipal Disclosure Practices and Audit Quality. Journal of Accounting and Public Policy 10: 245-266.

Craven, B. M dan Marston, C. L. 1999. Financial reporting on the internet by leading UK companies. The European Accounting Review 8(2): 321-333.

Cuillier, David dan Suzanne J. Piotrowski. 2009. Internet information-seeking and its relation to support for access to government records. Government Information Quarterly 26: 441-449.

Falkman, Par dan Torbjorn Tagesson. 2008. Accrual Accounting does not Necessarily Mean Accrual Accounting: Factors that counteract complieance with accounting standards in 
Swedish Municipal Accounting. Scandinavian Journal of Management 24 (3): 271 283.

Hilmi, Amiruddin Zul dan Dwi Martani. 2012. Analisis faktor-faktor yang mempengaruhi tingkat pengungkapan laporan keuangan pemerintah provinsi. Simposium Nasional Akuntansi XV Ikatan Akuntan Indonesia. Banjarmasin.

Ingram, Robert W. 1984. Economic Incentives and the Choice of State Government Accounting Practices. Journal of Accounting Research 22 (1): 126-144.

Khan, Mohd Noor Azli Ali dan Noor Azizi Ismail. 2012. A Review of E-Financial Reporting Research. Journal of Internet and e-business Studies Volume 2012 (2012).

Khasanah, Nur Lailatul dan Shiddiq Nur Rahardjo. 2014. Pengaruh Karakteristik, Kompleksitas, dan Temuan Audit Terhadap Tingkat Pengungkapan Laporan Keuangan Pemerintah Daerah. Diponegoro Journal Of Accounting 3 (3): 1-11.

Kusumawati, Dwi Novi. 2003. Faktor-faktor yang Mempengaruhi Intensi Penggunaan Web Site Perusahaan Go-Public Dalam Proses Pengambilan Keputusan Investasi oleh Investor Potensial. Simposium Nasional Akuntansi VI Ikatan Akuntan Indonesia. Surabaya.

Laswad, Fawzi., Richard Fisher., dan Peter Oyelere. 2005. Determinants of voluntary internet financial reporting by local government authorities. Journal of Accounting and Public Policy 24: 101-102.

Liestiani, Annisa. (2008). Pengungkapan LKPD Kabupaten/Kota di Indonesia untuk Tahun Anggaran 2006. Skripsi Sarjana. FEUI. Depok.

Mandasari, Putriesti. 2009. Practices of Mandatory Disclosure Compliance in Indonesian Local Government. Tesis Master. Universitas Sebelas Maret.

Martani, Dwi dan Annisa Lestiani. 2012. Disclosure in Local Government Financial Statements: the Case of Indonesia. Global Review of Accounting and Finance 3 (1): 67 - 84.

Nordiawan, Deddi. 2006. Akuntansi Sektor Publik. Jakarta: Salemba Empat.

Peraturan Pemerintah Republik Indonesia Nomor: 6 Tahun 2008. Tentang Pedoman Evaluasi Penyelenggaraan Pemerintahan Daerah.

Peraturan Menteri Dalam Negeri Nomor: 7A Tahun 2007. Tentang Tatacara Penyampaian Informasi dan Tanggapan atau Saran dari Masyarakat atas Laporan Penyelenggaraan Pemerintahan Daerah.

Peraturan Pemerintah Republik Indonesia Nomor: 56 Tahun 2005. Tentang Sistem Informasi Keuangan Daerah.

Peraturan Pemerintah Republik Indonesia Nomor: 105 Tahun 2000. Tentang Pengelolaan dan Pertanggungjawaban Keuangan Daerah.

Pernyataan Standar Akuntansi Keuangan (PSAK) Nomor: 1 Tahun Per 1 Juli 2009. Tentang Penyajian Laporan Keuangan.

Puspita, Rora., dan Dwi Martani. 2012. Analisis pengaruh kinerja dan karakteristik pemda terhadap tingkat pengungkapan dan kualitas informasi dalam website pemda. Simposium Nasional Akuntansi XV Ikatan Akuntan Indonesia. Banjarmasin. 
Rahman P, Aditya., Sutaryo dan Agus Budiatmanto. 2013. Determinan Internet Financial Local Government Reporting di Indonesia. Simposium Nasional Akuntansi XV Ikatan Akuntan Indonesia XVI. Manado.

Sandoval-Almazan, Rodrigo., dan J. Ramon Gil-Garcia. 2011. Are government internet portals evolving towards more interaction, participation, and collaboration? Revisiting the rhetoric of e-government among municipalities. Government Information Quarterly 29: S72-S81.

Sekaran, Uma. 2003. Research Methods for Business. Jakarta: Salemba Empat.

Serrano, C., Mar R., dan Pilar P. 2008. Factors Influencing E-Disclosure In Local Public Administrations. Documento de Trabajo-03 Facultad de Ciencias Económicas y Empresariales Universidad de Zaragoza.

Standar Profesional Akuntan Publik (SPAP) No. 1. Tentang Penyajian Laporan Keuangan .

Suhardjanto, Djoko dan Sigit Indra Lesmana. 2010. Pengaruh Karakteristik Pemerintah Daerah Terhadap Tingkat Pengungkapan Wajib Di Indonesia. Prestasi 6 (2): 1411-1497.

Syafitri, Febriyani. 2012. Analisis Pengaruh Karakteristik Pemerintah Terhadap Tingkat Pengungkapan Laporan Keuangan. Skripsi: dipublikasikan http://lib.ui.ac.id/file?file=digital/20319555-S-PDF-Febriyani\%20Syafitri.pdf. Diakses 13 Februari 2019.

Suwardjono. 2005. Teori Akuntansi: Perekayasaan Pelaporan Keuangan. Edisi Ketiga. Yogyakarta: BPFE

Undang-Undang Nomor: 32 Tahun 2004 pasal 184 ayat 1. Tentang Pemerintahan Daerah.

Undang-Undang Nomor: 33 Tahun 2004 pasal 28 ayat 2. Tentang Perimbangan Keuangan Antara Pemerintah Pusat dan Pemerintahan Daerah.

Undang-Undang Nomor: 14 Tahun 2008. Tentang Keterbukaan Informasi Publik. 